\title{
Does mobile phone use of women during pregnancy cause hearing problems in infants? Preliminary observation
}

\author{
Hava Bektaş ${ }^{1}$ (D), Süleyman Daşdağ ${ }^{2}$ (D), Mehmet Selçuk Bektaş ${ }^{3}$ \\ ${ }^{1}$ Department of Biophysics, Medical School, Van Yïziincii Yul University, Van, Turkey \\ ${ }^{2}$ Department of Biophysics, Medical School, İstanbul Medeniyet University, Istanbul, Turkey \\ ${ }^{3}$ Division of Neonatology, Clinic of Pediatrics, Lokman Hekim Hospital, Van, Turkey
}

\begin{abstract}
Objective: Some studies have claimed that long-term conversation with mobile phones can cause hearing loss. However, it has not been investigated whether exposure to mobile phones during pregnancy affects the hearing of babies in the womb. Therefore, the aim of this human study was to investigate the effects of intrauterine radiofrequency radiation (RFR) exposure emitted from mobile phones on the hearing of newborns.

Methods: The study population comprised 149 newborns. Pregnant women in this study were divided into 4 groups according to RFR exposure duration, such as non-exposure to RFR, exposure to RFR for 2-15 $\mathrm{min} /$ day, exposure to RFR for 15-60 $\mathrm{min} /$ day, and exposure to RFR for more than $60 \mathrm{~min} /$ day. The results of the hearing screening analyses of the newborns, which were performed using transiently evoked otoacoustic emission and auto auditory brainstem response, were investigated retrospectively.

Results: The results of this study indicated that 900 and 1800 $\mathrm{MHz}$ RFR exposure during pregnancy did not cause hearing loss in newborns.

Conclusion: In conclusion, we observed that the hearing sensitivity and peripheral sound perception of newborns were not affected by RFR exposure emitted from mobile phones during the intrauterine period. Further studies should be performed to illuminate the subject.
\end{abstract}

Keywords: Radio frequency radiation, mobile phone, pregnant women, infant, hearing loss.

\section{Introduction}

In recent years, exposure to radiofrequency radiation (RFR) emitted from wireless devices such as mobile phones, game consoles, internet service providers, etc.,

\section{Özet: Kadınların gebelik esnasında cep telefonu kullanımı bebeklerde işitme sorunlarına sebep oluyor mu? Ön gözlem}

Amaç: Bazı çalışmalarda, cep telefonları ile uzun süreli görüşme yapmanın işitme kaybına neden olabileceği ileri sürülmektedir. Ancak gebelik esnasında cep telefonu kullanımının anne karnındaki bebeklerin işitme yetileri üzerinde etkileri olup olmadığı araştırılmamıştır. Bu nedenle, insan popülasyonu üzerindeki bu çalışmamızdaki amacimız cep telefonlarından yayılan intrauterin radyofrekans radyasyonuna (RFR) maruz kalmanın yenidoğanların işitme yetileri üzerindeki etkilerini araştırmaktı.

Yöntem: Çalışma popülasyonu 149 yenidoğandan oluşmaktadır. Çalışmadaki gebeler, RFR maruziyet süresine göre 4 gruba ayrilmiş olup bunlar, RFR'ye maruz kalmama, RFR'ye 2-15 dakika/gün maruziyet, RFR'ye 15-60 dakika/gün maruziyet ve RFR'ye 60 dakika/gün'den fazla maruziyet gruplarıdır. Yenidoğanlarda geçici uyarılmış otoakustik emisyon ve oto-işitsel beyin sapı yanıtı şeklinde gerçekleştirilen işitme taraması analizlerinin sonuçlar retrospektif olarak araştırılmıştır.

Bulgular: Bulgular, gebelik esnasında 900 ve 1800 MHz RFR maruziyetinin yenidoğanlarda işitme kaybına yol açmadığını göstermiştir.

Sonuç: Sonuç olarak, yenidoğanlarda işitme hassasiyetinin ve çevre sesi algısının intrauterin dönemde cep telefonlarının yaydığ RFR maruziyetinden etkilenmediğini gözlemledik. Konuyu açıklığa kavuşturmak için ek çalışmalar yapılmalıdır.

Anahtar sözcükler: Radyofrekans radyasyonu, cep telefonu, gebeler, bebek, işitme kaybi.

has significantly increased due to the widespread usage these devices. Various studies regarding this topic have reported that exposure to RFR could influence neurodevelopment, the blood-brain barrier, demyelina-

Correspondence: Süleyman Daşdağ, MD. Department of Biophysics, Medical School, İstanbul Medeniyet University, Istanbul, Turkey. e-mail: sdasdag@gmail.com / Received: May 1, 2020; Accepted: June 14, 2020

Please cite this article as: Bektaş H, Daşdă̆ S, Bektaş MS. Does mobile phone use of women during pregnancy cause hearing problems in infants? Preliminary observation. Perinatal Journal 2020;28(2):101-107. doi:10.2399/prn.20.0282013 
tion, neurotransmitter release, lead to alterations in the regulation of the cell cycle, and change intracellular and some molecular pathways, and cause alterations in the central nervous system. ${ }^{[1]}$

The most important groups in terms of health problems that electromagnetic field (EMF) exposure can affect are pregnant women and children. In a workshop organized by the World Health Organization in Istanbul, Turkey, in 2004, the sensitivity of children to EMFs was discussed and it was emphasized that studies on this subject should be increased. ${ }^{[2]}$

The studies have shown that RFR may disrupt the structure of biomolecules, such as proteins, lipids, and $\mathrm{DNA}^{[3-6]}{ }^{[3}$ change gene expression ${ }^{[7]}$ and result in oxidative stress during the early pregnancy period. The amount of RFR absorbed by the body has shown alterations during the gestation period due to changes in the amount of water in the body. ${ }^{[8]}$ The nervous system of a baby forms rapidly during the prenatal period and the brain tissues have high conductivity owing to their high water content..$^{[9]}$ Maskey et al..$^{[10]}$ reported that the auditory brainstem region is sensitive to chronic exposure to RFR [835 MHz, 4.0 W/kg specific absorption rate (SAR)], which may influence the function of the central auditory system. Moreover, the results of ABR tests on rats exposed to RFR also displayed a significant threshold elevation that might have originated from auditory dysfunction. ${ }^{[10]}$

Hearing loss, which is loss of the sense of auditory partially or completely, originates from some defects in the outer or middle ear. These defects may slow the transfer of sound waves and even prevent them from transferring. Another type of the hearing loss originates from damage to hair cells in the inner ear. Damage in the auditory nerve itself or in the brain pathways may cause central hearing loss. The incidence of hearing loss in live birth newborns in was reported as 1-6/1000 babies, and this rate increased up to $10 / 1000$ in newborns in risk groups. ${ }^{[11]}$ About $50 \%-60 \%$ of congenital hearing loss are hereditary. It was reported that $40 \%-50 \%$ of congenital hearing losses arise from disorders, such as intrauterine infections, hypoxia, hyperbilirubinemia, prematurity, low birth weight, ototoxic drug usage, hypothyroidism, sepsis, meningitis, and persistent pulmonary hypertension. ${ }^{[12]}$ These risk factors adversely affect cochlea.
Transient evoked otoacoustic emissions (TEOAE) and auditory brainstem response (ABR) tests are analyses that are used to detect hearing loss in infants during the early period. These tests are non-invasive and they ensure objective and physiological measurements. ${ }^{[13]}$ Eighth nerve and auditory brain stem dysfunction cannot be detected by the TEOAE test. Despite hearing loss, a normal TEOAE response may be received in these types of pathologies. Therefore, TEOAE is not an adequate screening test for infants with neurological hearing loss risk factors. ABR has been used for many years as an electrophysiological measurement that evaluates the hearing function in the section from the 8 th nerve to the brainstem. In the $\mathrm{ABR}$ test, the electrical responses of the brainstem auditory way and auditory nerve are evaluated against click stimulus given by electrodes placed on the forehead, mastoid, and neck of the patient. Nowadays, the TEOAE and ABR tests are generally used together in newborn clinics for hearing loss screening. If the newborn does not pass the TEOAE test at least twice, the ABR test needs to be applied 3 months afterwards. However, if one or more of the hearing loss risk factors are present in the newborn, it is appropriate to perform the ABR test without waiting.

Studies carried out on the effects of RFR emitted from mobile phones on the auditory systems of fetuses and newborns are very limited. Investigations regarding this issue, the majority of which were carried out on animals, have had differences in terms of parameters, such as experimental setups, techniques, and SARs. These differences in the experimental setups and inconsistencies in the results of the studies have led to contradictions.

Some of previous studies have shown that RFR can cause hearing loss in both humans and animals. ${ }^{[1,10,14-22]}$ The aim of the current study was to reveal whether the auditory system development of babies in the womb was affected by the mobile phone usage of their mothers during pregnancy. The mobile phones used by pregnant women in this study consisted of smart phones (SAR values were between $0.57-0.65 \mathrm{~W} / \mathrm{kg}$ ). 3G technology was used in Turkey at the time of this study. Digitally enhanced cordless telecommunication was not used by the pregnant women. The results of the TEOAE and ABR tests carried out on infants who met the acceptance criteria, which had previously been determined for this study, were used. 


\section{Methods}

The study was conducted in accordance with the Declaration of Helsinki and the protocol was approved by the Ethics Committee of the Medical Faculty, Van Yüzüncü Yil University (Report No: 2019/14-04). Primarily, the pregnant women accepted into the study were identified by excluding women who had received any medical treatment, had a chronic systemic disease, multiple pregnancies, hearing loss in their families, and consanguineous marriage. The study comprised 149 volunteer pregnant women aged between 18 and 40 years. All of the pregnant women gave their signed informed consent prior to beginning the study. The pregnant women were divided into 4 groups depending on the daily usage time of their mobile phones. Control Group: Non-mobile phone users during pregnancy $(n=37)$, Group 1: Mobile phone users for 2-15 min per day $(\mathrm{n}=39)$, Group 2: Mobile phone users for 15-60 min per day $(\mathrm{n}=37)$, Group 3: Mobile phone users for more than $60 \mathrm{~min}$ per day $(\mathrm{n}=36)$. Daily mobile phone usage times of the pregnant women were confirmed using the bills obtained from their GSM service providers.

Before the babies were discharged, TEOAE tests (TEOAE1 and TEOAE2), which were first hearing tests used, were conducted. The tests were administered with an Ero-scan (Madsen Accuscreen, Natus Medical Denmark ApS., Taastrup, Denmark) in a test environment of self-noise at $<45 \mathrm{~dB}$. The probe was inserted into the external auditory canal of the patients for calibration and then the test was started. The stimulus intensity given in the TEOAE was 26-36 dB. The screening results were automatically determined by the Ero-scan with passed/failed criteria. If Pass was displayed, the hearing screening was recorded as a pass. In this study, babies who had risk factors that would cause hearing loss (hearing loss in the family and consanguineous marriage, birth defects, infections such as toxoplasmosis, measles, or herpes, etc.) were excluded.

The ABR test was administered using an auditory evoked potential analyzer (EP25, Interacoustics, Middelfart, Denmark) in a soundproof room. When the subjects were in natural sleep or hypnosis after being given $10 \%$ chloral hydrate, the reference electrode and recording electrode were placed onto the ipsilateral mastoid and forehead, and alternating click stimuli was administered with an interelectrode resistance of $\leq 5 \mathrm{~K} \Omega$ and a filtering bandwidth of $100-3000 \mathrm{~Hz}$. The scan was performed for a duration of $10 \mathrm{~ms}$. The results of the hearing screening analyses of the newborns performed using the TEOAE and ABR tests were achieved with archive scan.

It was determined by the covariance analysis if the confounding factors such as maternal and paternal age; age of the father; weight gained by the mother during pregnancy; number of doctor visits during pregnancy; phone SAR value; type of birth; fetal distress; presence of meconium; toxoplasmosis; rubella; cytomegalovirus; presence of herpes simplex and HIV; placental disease; systemic diseases; condition of the amniotic fluid; multiple pregnancies; stillbirth; gestational vitamin usage comprising ferritin, vitamin $\mathrm{D}$, and folic acid; exposure to radiation; urinary tract infections; vaginitis; chorioamnionitis; smoking and alcohol consumption; amount of daily cigarettes smoked; presence of a base station in the neighborhood, etc. had any impact or not. It was found that the confounding factors had no impact on the groups as $\mathrm{p}$ value was $>0.05$.

Descriptive statistics for the continuous variables were presented as the mean, standard deviation, and minimum and maximum values, while count and percentages were used for the categorical variables. For determination of linear relationships between the categorical variables, the chi square test was performed. Statistical significance was accepted as $\mathrm{p}<0.05$ and the Statistical Package for the Social Sciences (SPSS) v.13 (SPSS Inc., Chicago, IL, USA) software was used for all of the statistical computations. Moreover, due to the fact that the rate of success in hearing tests (p) ranged from $75 \%$ to $95 \%$ in the results of a previous study by Yorgancilar et al., ${ }^{[14]}$ the success rate was accepted as $85 \%$ in the current study. Furthermore, for the 0.05 type I error rate, the $Z$ value and the effect size were assumed as 1.96 and $6 \%$, respectively. Based on this information, the necessary sample size was determined as a minimum of 136 individuals according to the equation for sample size calculation $[\mathrm{n}=\mathrm{Z} 2(\mathrm{p} \times \mathrm{q}) / \mathrm{d} 2]$. In other words, the statistical power (sample size) of the current study was appropriate.

\section{Results}

Herein, $91.9 \%$ of the newborns in the control group, $89.7 \%$ of those in Group 1, $97.3 \%$ of those in Group 2, and $80.6 \%$ of those in Group 3 passed the TEOAE 1 test (Table 1). Since $p>0.05$, the results of the TEOAE1 test were not statistically associated with speech groups. Herein, $80.0 \%$ of the newborns in the control group, 
$50.0 \%$ of those in Group 1, 100.0\% of those in Group 2, and $65.0 \%$ of those in Group 3 passed the TEOAE2 test (Table 2). No significant difference was found when the groups were compared in terms of the results of TEOAE2 test $(\mathrm{p}=0.280)$. Only 58 of the babies included in the study were administered the ABR test because they had passed the 2 earlier tests (TEOAE1 and TEOAE2) and they eventually passed all of the tests.

\section{Discussion}

The newborns successfully passed the TEOAE and ABR tests. Mobile phones used by the pregnant mothers emitted between 900 and $1800 \mathrm{MHz}$ RFR according to the information that was received from the GSM service providers. No statistically significant differences were found among the speech groups according to the results of the hearing tests. The results showed that exposure to between 900 and $1800 \mathrm{MHz}$ RFR during the intrauterine period did not affect the hearing status of the newborns. Moreover, exposure durations of the infants to RFR during the prenatal period were also found to not have any effect.
The effects of RFR exposure on fetuses and newborns are still not well known. Several studies have reported that even RFR exposure below the safety standards of the International Commission on NonIonizing Radiation Protection have caused harmful effects on human health. ${ }^{[23]}$

Fetuses have a high number of stem cells, which are responsible for the formation of the fetal neural system. ${ }^{[24]}$ Stem cells are very susceptible to toxins and RFR. Thus, exposure of the fetus to EMFs can increase the risk of adverse health outcomes. ${ }^{[25]}$ Several studies have reported harmful effects related to RFR exposure in human stem cells. ${ }^{[2,27]}$ A study carried out on the Danish National Birth Cohort indicated a positive and dose-dependent relationship between the use of the mobile phones by mothers during pregnancy and the behavioral problems of their offspring. ${ }^{[28-30]}$ Moreover, brain development is quite responsive to RFR exposure during the prenatal period. ${ }^{[23]}$ Hardell and Sage ${ }^{[31]}$ noted that RFR exposure could induce some changes in the brain and neural system functions, and children should be warned about the unknown biological complications of prolonged RFR exposure. Furthermore, it was stat-

Table 1. Results of the TEOAE1 test.

\begin{tabular}{|c|c|c|c|c|c|}
\hline \multirow[b]{2}{*}{ Talking } & & \multicolumn{4}{|c|}{ TEOAE1 } \\
\hline & & Passed & Failed (bilateral) & Failed (unilateral) & Total \\
\hline \multirow[t]{4}{*}{ Control } & Count & 34 & 2 & 1 & 37 \\
\hline & $\%$ while talking & $91.9 \%$ & $5.4 \%$ & $2.7 \%$ & $100.0 \%$ \\
\hline & $\%$ within TEOAE1 & $25.4 \%$ & $20.0 \%$ & $20.0 \%$ & $24.8 \%$ \\
\hline & $\%$ of total & $22.8 \%$ & $1.3 \%$ & $0.7 \%$ & $24.8 \%$ \\
\hline \multirow[t]{4}{*}{ 2-15 min/day (Group 1) } & Count & 35 & 3 & 1 & 39 \\
\hline & $\%$ while talking & $89.7 \%$ & $7.7 \%$ & $2.6 \%$ & $100.0 \%$ \\
\hline & $\%$ within TEOAE1 & $26.1 \%$ & $30.0 \%$ & $20.0 \%$ & $26.2 \%$ \\
\hline & $\%$ of total & $23.5 \%$ & $2.0 \%$ & $0.7 \%$ & $26.2 \%$ \\
\hline \multirow[t]{4}{*}{ 15-60 min/day (Group 2) } & Count & 36 & 0 & 1 & 37 \\
\hline & $\%$ while talking & $97.3 \%$ & $0.0 \%$ & $2.7 \%$ & $100.0 \%$ \\
\hline & $\%$ within TEOAE1 & $26.9 \%$ & $0.0 \%$ & $20.0 \%$ & $24.8 \%$ \\
\hline & $\%$ of total & $24.2 \%$ & $0.0 \%$ & $0.7 \%$ & $24.8 \%$ \\
\hline \multirow[t]{4}{*}{$>60 \mathrm{~min} /$ day (Group 3) } & Count & 29 & 5 & 2 & 36 \\
\hline & $\%$ while talking & $80.6 \%$ & $13.9 \%$ & $5.6 \%$ & $100.0 \%$ \\
\hline & $\%$ within TEOAE1 & $21.6 \%$ & $50.0 \%$ & $40.0 \%$ & $24.2 \%$ \\
\hline & $\%$ of total & $19.5 \%$ & $3.4 \%$ & $1.3 \%$ & $24.2 \%$ \\
\hline \multirow[t]{4}{*}{ Total } & Count & 134 & 10 & 5 & 149 \\
\hline & $\%$ while talking & $89.9 \%$ & $6.7 \%$ & $3.4 \%$ & $100.0 \%$ \\
\hline & $\%$ within TEOAE1 & $100.0 \%$ & $100.0 \%$ & $100.0 \%$ & $100.0 \%$ \\
\hline & $\%$ of total & $89.9 \%$ & $6.7 \%$ & $3.4 \%$ & $100.0 \%$ \\
\hline
\end{tabular}

Pearson's chi-square test $=6.674 ; p=0.352$ 
ed that RFR exposure during pregnancy could cause adverse health effects in the fetuses, even if the exposure levels were within the legal levels accepted by many countries. ${ }^{[23]}$ Some studies have reported that exposure to RFR could change gene expression during gestation. ${ }^{[7,32]}$ However, the few epidemiologic studies that have been conducted were insufficient to exhibit a potential association between developmental conclusions and prenatal RFR exposure. ${ }^{[3,34]}$

Many studies have researched the effects of RFR on the central or peripheral auditory system. Some researchers have investigated the effects of exposure to RFR on the central auditory system using the ABR test or potentially related auditory incidents; however, no effects were determined. Similarly, several studies have been performed using otoacoustic emissions; however, it was reported that RFR exposure did not cause any effects on the inner ear. ${ }^{[16-19]}$ When the effects of mobile phone-like $900 \mathrm{MHz}$ RFR on the cochlear function of rats was investigated, no variations in the DPOAE values were determined. ${ }^{[20]}$ Similarly, in another study, it was reported that 10 min RFR exposure at maximum power ( $2 \mathrm{~W}$ at $900 \mathrm{MHz}$ or $1 \mathrm{~W}$ at $1800 \mathrm{MHz}$ ) did not cause any alterations in the DPOAE values. ${ }^{[21]}$ On the other hand, it was reported that $24 \mathrm{~h}$ /day long-term exposure (1 year) to $2.4 \mathrm{GHz}$ RFR significantly affected DPOAE values and could cause impairment the hearing of adult Wistar rats. ${ }^{[14]}$ In a recent study of mice during the postnatal period, following exposure to $1850 \mathrm{MHz}$ RFR, no significant changes were observed in the hearing threshold of the ABR test. It was reported that RFR might directly affect brainstem auditory circuits, but did not change the general sound perception. ${ }^{[1]}$ In another study, no significant effects were observed in the TEOAE results of 30 cases after exposure to between 900 and $1800 \mathrm{MHz}$ RFR emitted from mobile phones. ${ }^{[2]}$ These contradictory results may have been due to the dissimilar designs of the RFR sources. ${ }^{[3,36]}$ In a study of the cochlear functions of infant rabbits exposed to RFR during the intrauterine and extrauterine periods, it was reported that GSMlike RFR during the intrauterine period was less harmful when compared to that in the extrauterine period. This was due to the fact that the water content of the middle and inner ear, and the amniotic fluid during the intrauterine period, have a protective role. ${ }^{[3]}$

Table 2. Results of the TEOAE2 test.

\begin{tabular}{|c|c|c|c|c|c|}
\hline \multirow[b]{2}{*}{ Talking } & & \multicolumn{4}{|c|}{ TEOAE2 } \\
\hline & & Passed & Failed (bilateral) & Failed (unilateral) & Total \\
\hline \multirow[t]{4}{*}{ Control } & Count & 12 & 2 & 1 & 15 \\
\hline & $\%$ while talking & $80.0 \%$ & $13.3 \%$ & $6.7 \%$ & $100.0 \%$ \\
\hline & $\%$ within TEOAE2 & $30.0 \%$ & $20.0 \%$ & $25.0 \%$ & $27.8 \%$ \\
\hline & $\%$ of total & $22.2 \%$ & $3.7 \%$ & $1.9 \%$ & $27.8 \%$ \\
\hline \multirow[t]{4}{*}{ 2-15 min/day (Group 1) } & Count & 4 & 3 & 1 & 8 \\
\hline & $\%$ while talking & $50.0 \%$ & $37.5 \%$ & $12.5 \%$ & $100.0 \%$ \\
\hline & $\%$ within TEOAE2 & $10.0 \%$ & $30.0 \%$ & $25.0 \%$ & $14.8 \%$ \\
\hline & $\%$ of total & $7.4 \%$ & $5.6 \%$ & $1.9 \%$ & $14.8 \%$ \\
\hline \multirow[t]{4}{*}{ 15-60 min/day (Group 2) } & Count & 11 & 0 & 0 & 11 \\
\hline & $\%$ while talking & $100.0 \%$ & $0.0 \%$ & $0.0 \%$ & $100.0 \%$ \\
\hline & $\%$ within TEOAE2 & $27.5 \%$ & $0.0 \%$ & $0.0 \%$ & $20.4 \%$ \\
\hline & $\%$ of total & $20.4 \%$ & $0.0 \%$ & $0.0 \%$ & $20.4 \%$ \\
\hline \multirow[t]{4}{*}{$>60 \mathrm{~min} /$ day (Group 3) } & Count & 13 & 5 & 2 & 20 \\
\hline & $\%$ while talking & $65.0 \%$ & $25.0 \%$ & $10.0 \%$ & $100.0 \%$ \\
\hline & $\%$ within TEOAE2 & $32.5 \%$ & $50.0 \%$ & $50.0 \%$ & $37.0 \%$ \\
\hline & $\%$ of total & $24.1 \%$ & $9.3 \%$ & $3.7 \%$ & $37.0 \%$ \\
\hline \multirow[t]{4}{*}{ Total } & Count & 40 & 10 & 4 & 54 \\
\hline & $\%$ while talking & $74.1 \%$ & $18.5 \%$ & $7.4 \%$ & $100.0 \%$ \\
\hline & $\%$ within TEOAE2 & $100.0 \%$ & $100.0 \%$ & $100.0 \%$ & $100.0 \%$ \\
\hline & $\%$ of total & $74.1 \%$ & $18.5 \%$ & $7.4 \%$ & $100.0 \%$ \\
\hline
\end{tabular}

Pearson's chi-square test $=7.470 ; p=0.280$. 
A possible explanation for the results of the current study may be the protective effects of maternal estrogen and corticosteroids. It is well-known that maternal estrogen increases during pregnancy. The estrogen receptor, which has $\beta$-mediated neuroprotective efficacy involving the brain-derived neurotrophic factor in the auditory system, protects the functions of the inner ear. ${ }^{[3]]}$ Moreover, maternal corticosteroids, which increase during the prenatal period, develop the hearing system and protect the ear from the detrimental effects of the RFR emitted by mobile phones. ${ }^{[3]}$

\section{Conclusion}

Consequently, the data herein showed that the hearing sensitivity and peripheral sound perception of newborns were not affected by RFR exposure emitted by mobile phones during the intrauterine period. However, it should be stated that RFR exposure during the prenatal period could cause circuit alterations in the auditory nervous system, without influencing the functions of sound perception. To our knowledge, this study was the first human study to investigate the effects of mobile phone use by mothers during the prenatal period on the sense of hearing of newborns. To date, among the studies carried out on this subject, there has not been any consistency in terms of experimental parameters and the results of the investigations. Thus, characterization of the exposure to RFR may be significant to further research the mechanisms of the action EMFs.

Conflicts of Interest: No conflicts declared.

\section{References}

1. Kim JH, Huh YH, Lee JH, Jung JY, Ahn SC, Kim HR. Early exposure to radiofrequency electromagnetic fields at 1850 $\mathrm{MHz}$ affects auditory circuits in early postnatal mice. Sci Rep 2019;9:377. [PubMed] [CrossRef]

2. Kheifets L, Repacholi M, Saunders R, van Deventer E. The sensitivity of children to electromagnetic fields. Pediatrics 2005;116:e303-13. [PubMed] [CrossRef]

3. Lai H, Singh NP. Single- and double-strand DNA breaks in rat brain cells after acute exposure to radiofrequency electromagnetic radiation. Int J Radiat Biol 1996;69:513-21. [PubMed] [CrossRef]

4. Dasdag S, Akdag MZ, Aksen F, Bashan M, Buyukbayram H. Does $900 \mathrm{MHz}$ GSM mobile phone exposure affect rat brain? Electromagn Biol Med 2004;23:201-14. [CrossRef]

5. Dasdag S, Akdag MZ, Ulukaya E, Uzunlar AK, Ocak AR. Effect of mobile phone exposure on apoptotic glial cells and status of oxidative stress in rat brain. Electromagn Biol Med 2009;28:342-54. [PubMed] [CrossRef]

6. Dasdag S, Akdag MZ, Kizil G, Kizil M, Cakir DU, Yokus B. Effect of $900 \mathrm{MHz}$ Radio frequency radiation on beta amyloid protein, protein carbonyl, and malondialdehyde in the brain. Electromagn Biol Med 2012;31:67-74. [PubMed] [CrossRef]

7. Pyrpasopoulou A, Kotoula V, Cheva A, Hytiroglou P, Nikolakaki E, Magras IN, et al. Bone morphogenetic protein expression in newborn rat kidneys after prenatal exposure to radiofrequency radiation. Bioelectromagnetics 2004;25:21627. [PubMed] [CrossRef]

8. Keshvari J, Keshvari R, Lang S. The effect of increase in dielectric values on specific absorption rate (SAR) in eye and head tissues following 900, 1800 and $2450 \mathrm{MHz}$ radio frequency (RF) exposure. Phys Med Biol 2006;51:1463-77. [PubMed] [CrossRef]

9. Otto M, von Mühlendahl KE. Electromagnetic fields (EMF): do they play a role in children's environmental health $(\mathrm{CEH})$ ? Int J Hyg Environ Health 2007;210:635-44. [PubMed] [CrossRef]

10. Maskey D, Kim HG, Suh MW, Roh GS, Kim MJ. Alteration of glycine receptor immunoreactivity in the auditory brainstem of mice following three months of exposure to radiofrequency radiation at SAR 4.0 W/kg. Int J Mol Med 2014;34: 409-19. [PubMed] [CrossRef]

11. European Consensus Statement on Neonatal Hearing Screening Finalized at the European Consensus Development Conference on Neonatal Hearing Screening. Milan, 15-16 May 1998. Acta Paediatr 1999;88:107-8. [PubMed] [CrossRef]

12. Cunningham M, Cox EO; Committee on Practice and Ambulatory Medicine and the Section on Otolaryngology and Bronchoesophagology. Hearing assessment in infants and children: recommendations beyond neonatal screening. Pediatrics 2003;111:436-40. [PubMed] [CrossRef]

13. Markides A. Age at fitting of hearing aids and speech intelligibility. Br J Audiol 1986;20:165-7. [PubMed] [CrossRef]

14. Yorgancilar E, Dasdag S, Akdag MZ, Akkus Z, Akdag M, Topcu I. Does all-day and long-term exposure to radiofrequency radiation emitted from $\mathrm{Wi}-\mathrm{Fi}$ affect hearing? Biotechnol Biotechnol Equip 2017;31:1204-9. [CrossRef]

15. Oktay MF, Dasdag S. Effects of intensive and moderate cellular phone use on hearing function. Electromagn Biol Med 2006;25:13-21. [PubMed] [CrossRef]

16. Mora R, Crippa B, Mora F, Dellepiane M. A study of the effects of cellular telephone microwave radiation on the auditory system in healthy men. Ear Nose Throat J 2006;85: 160-3. [PubMed]

17. Ozturan O, Erdem T, Miman MC, Kalcioglu MT, Oncel S. Effects of the electromagnetic field of mobile telephones on hearing. Acta Otolaryngol 2002;122:289-93. [PubMed] [CrossRef]

18. Monnery PM, Srouji EI, Bartlett J. Is cochlear outer hair cell function affected by mobile telephone radiation? Clin Otolaryngol Allied Sci 2004;29:747-9. [PubMed] [CrossRef] 
19. Janssen $\mathrm{T}$, Boege $\mathrm{P}$, von Mikusch-Buchberg J, Raczek J. Investigation of potential effects of cellular phones on human auditory function by means of distortion product otoacoustic emissions. J Acoust Soc Am 2005;117:1241-7. [PubMed] [CrossRef]

20. Galloni P, Lovisolo GA, Mancini S, Parazzini M, Pinto R, Piscitelli M, et al. Effects of $900 \mathrm{MHz}$ electromagnetic fields exposure on cochlear cells' functionality in rats: evaluation of distortion product otoacoustic emissions. Bioelectromagnetics 2005;26:536-47. [PubMed] [CrossRef]

21. Parazzini M, Bell S, Thuroczy G, Molnar F, Tognola G, Lutman ME, et al. Influence on the mechanisms of generation of distortion product otoacoustic emissions of mobile phone exposure. Hear Res 2005;208:68-78. [PubMed] [CrossRef]

22. Uloziene I, Uloza V, Gradauskiene E, Saferis V. Assessment of potential effects of electromagnetic fields of mobile phones on hearing. BMC Public Health 2005;5:39. [PubMed] [CrossRef]

23. Bektas H, Dasdag S. Effects of radiofrequencies emitted from mobile phones and $\mathrm{Wi}-\mathrm{Fi}$ on pregnancy. Journal of International Dental and Medical Research 2017;10:108495.

24. Franco SJ, Gil-Sanz C, Martínez-Garay I, Espinosa A, Harkins-Perry SR, Ramos C, et al. Fate-restricted neural progenitors in the mammalian cerebral cortex. Science 2012; 337:746-9. [PubMed] [CrossRef]

25. Kheifets L, Repacholi M, Saunders R, van Deventer E. The sensitivity of children to electromagnetic fields. Pediatrics 2005;116:e303-33. [PubMed] [CrossRef]

26. Czyz J, Guan K, Zeng Q, Nikolova T, Meister A, Schönborn F, et al. High frequency electromagnetic fields (GSM signals) affect gene expression levels in tumor suppressor p53deficient embryonic stem cells. Bioelectromagnetics 2004; 25:296-307. [PubMed] [CrossRef]

27. Belyaev IY. Dependence of non-thermal biological effects of microwaves on physical and biological variables: implications for reproducibility and safety standards. In: Giliani I, Soffritti $M$, editors. Non-thermal effects and mechanisms of interaciton between electromagnetic fields and living matter. An ICEMS monograph. Eur J Oncol Library Vol. 5. Bologna: National Institute for the Study and Control of Cancer and
Environmental Diseases "Bernardino Ramazzini”; 2010. p. $187-211$.

28. Divan HA, Kheifets L, Obel C, Olsen, J. Prenatal and postnatal exposure to cell phone use and behavioral problems in children. Epidemiology 2008;19:523-9. [PubMed] [CrossRef]

29. Divan HA, Kheifets L, Obel C, Olsen J. Prenatal cell phone use and developmental milestone delays among infants. Scand J Work Environ Health 2011:37:341-8. [PubMed] [CrossRef]

30. Sudan M, Kheifet L, Arah OA, Olsen J. On the association of cell phone exposure with childhood behaviour. J Epidemiol Community Health 2013;67:979. [PubMed] [CrossRef]

31. Hardell L, Sage C. Biological effects form electromagnetic field exposure and public exposure standards. Biomed Pharmacother 2007;62:104-9. [PubMed] [CrossRef]

32. Zhao R, Zhang S, Xu Z, Ju L, Lu D, Yao G. Studying gene expression profile of rat neuron exposed to $1800 \mathrm{MHz}$ radiofrequency electromagnetic fields with cDNA microassay. Toxicology 2007;235:167-75. [PubMed] [CrossRef]

33. Krewski D, Byus CV, Glickman BW, Lotz WG, Mandeville R, McBride ML, et al. Potential health risks of radiofrequency fields from wireless telecommunication devices. J Toxicol Environ Health B Crit Rev 2001;4:1-143. [PubMed] [CrossRef]

34. Krewski D, Byus CV, Glickman BW, Lotz WG, Mandeville $\mathrm{R}$, McBride ML, et al. Recent advances in research on radiofrequency fields and health. J Toxicol Environ Health B Crit Rev 2001;4:145-59. [PubMed] [CrossRef]

35. Kellenyi L, Thuroczy G, Faludy B, Lenard L. Effects of mobile GSM radiotelephone exposure on the auditory brainstem response (ABR). Neurobiology (Bp) 1999;7:79-81. [PubMed]

36. Hamblin DL, Wood AW, Croft RJ, Stough C. Examining the effects of electromagnetic fields emitted by GSM mobile phones on human event-related potentials and performance during an auditory task. Clin Neurophysiol 2004;115:1718. [PubMed] [CrossRef]

37. Budak GG, Muluk NB, Budak B, Öztürk GG, Apan A, Seyhan N. Effects of intrauterine and extrauterine exposure to GSMlike radiofrequency on distortion product otoacoustic emissions in infant male rabbits. Int J Pediatr Otorhinolaryngol 2009;73:391-9. [PubMed] [CrossRef] 